\title{
Analysis of Non-Isolated Bidirectional Active Clamped DC-DC Converter for PV and Battery Integrated Systems
}

\author{
S. Usha, C. Subramani, B. Dinesh Naidu and M. S. R. Vishnu Venkatesh \\ Department of EEE, SRM University, Kattakulathur, Chennai, Tamil Nadu, India; ushakarthick@gmail.com, \\ dineshbotcha91@gmail.com, vishnu2maddula@gmail.com
}

\begin{abstract}
Background/Objective: A novel soft switching technique is implemented in a Bidirectional DC-DC converter by using an Active clamped Auxiliary switch and in turn it achieves continuous current of inductor and operates at constant frequency is used to turn ON and turn OFF the switches. Methods/Statistical Analysis: The Power electronics converter systems have DC bus voltages they are connected to batteries or supercapacitors. Bidirectional converters which are connected to battery, supercapacitor allows them to charge or discharge. A new soft switching Bi-directional direct current to direct current converter is presented in this paper. This converter is operated in zero voltage and zero current switching, continuous inductor current and constant frequency that frequency is used to turn ON and turn OFF the switches. The switching stresses are reduced in this proposed method by auxiliary switches compared to traditional methods. The simulation results are obtained by using MATLAB software in this paper. Findings: The proposed converter is implemented by using an Auxiliary switch with soft switching technique. The output is ripple free DC voltage of 63.5V. Improvements: The Bidirectional Converter will operate at continuous inductor current also with less ripples in output voltage.
\end{abstract}

Keywords: Auxiliary Circuit, Continuous Inductor Current, DC-DC Converter, Power Electronics, Pulse Width Modulation, Soft-Switching

\section{Introduction}

In Space and automotive, the power electronics systems are widely used. These power electronic systems are integrated to DC bus through Bidirectional converters. Batteries and super capacitors which are used in power electronic system are allowed to charge or discharge. This converter may be isolated ${ }^{1}$ or non-isolated ${ }^{2}$ and it depends up on application. $\operatorname{In}^{1}$ achieving bidirectional power flow provides a simple, efficient and galvanically isolated topology that is especially attractive for use in battery charging. $\mathrm{In}^{2}$ non-isolated system uses an auxiliary circuit to obtain soft-switching of converter this leads to improve efficiency of converter.

In this proposed converter we are representing a non-isolated $\mathrm{Bi}$-directional converter which is inheritance of Buck/Boost converter. In Figure $1 S_{1}$ switch is going to operate as a boosting switch and $\mathrm{S}_{2}$ acts as boosting diode in which power transfer takes place from the lower voltage side $V_{\text {lo }}$ to the higher voltage side $\mathrm{V}_{\mathrm{hi}}$, and $\mathrm{S}_{1}$ acts as a bucking diode and $\mathrm{S}_{2}$ operates as a boosting diode where power transfer takes place from $\mathrm{V}_{\text {hi }}$ to $\mathrm{V}_{10}$.

Generally it's very easy to use soft-switching technique in Isolated Bidirectional direct current to direct current converter Converter when compared to Non-Isolated Bidirectional converter. As they are inheritance of half bridge and full bridge converters which uses inductive energy that is stored in transformer to discharge the capacitor which is present across the switches of converter. It's a little bit tough task to carry out for non-isolated converters due to the absence of transformer. There are several soft-switching techniques that are used previously and they can be differentiated as follows:

${ }^{*}$ Author for correspondence 


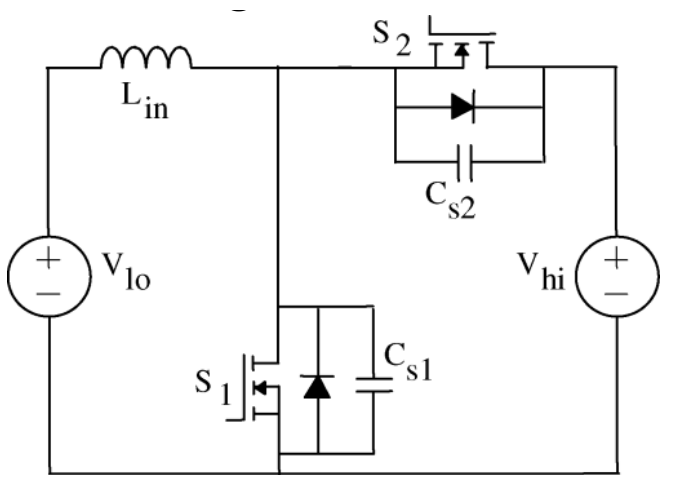

Figure 1. Conventional soft-switched Non-isolated DCDC converter.

The Converters proposed $\mathrm{in}^{3}$ and $^{4}$ are referred on circuitry in Figure 1 which are operated with the flow of current in both directions through inductor during every cycle. Two switches will on at different time periods, some times in each half-cycle, the stored energy of inductor is used to turn on other device with Zero Voltage Switching (ZVS), due to the impact of turning off switch. Demerits of this method are current in inductor contains ripple with a very high value which results in turn-off losses which in turn causes decrease in efficiency of converter.

Another method of approach is quasi-resonant, multi-resonant circuitries. By these techniques, the results of the converter are going to have high power stresses and this causes Bidirectional converter to operate at different switching frequencies which in turn causes complicate design in hardware. It becomes complicated while designing the filter components and magnetics when the converter operated at different switching frequencies. In case of the converter proposed $\mathrm{in}^{5}$ can be operated at constant frequency of switching but stress of the device remains same. A Bi-directional converter of fixed switching frequency resonant type is proposed in ${ }^{6}$, but this requires half bridge converters more than one in series which is costly.

The other method is to use auxiliary circuitry to guide the switching devices to operate in soft-switching mode as in ZVT converters which are proposed in ${ }^{7-11}$. Even though this is an improvement, compared to existing techniques, but it lags at complexity and cost. This complexity is due to use of four switches in which two auxiliary switches are used for two main switches. Conventional control switches replaced by two stage buck boost converter for improving the system quality ${ }^{12}$ and efficiency. Multi Port Converters implemented to produce a bidirectional
Table 1. Design specifications of the proposed converter

\begin{tabular}{|c|c|}
\hline Parameters & Values \\
\hline PV Input Voltage & $70 \mathrm{~V}$ \\
\hline Battery Input Voltage & $36 \mathrm{~V}$ \\
\hline Inductor & $\mathrm{Lr} 1=\mathrm{Lr} 2=12.5 \mu \mathrm{H}, \mathrm{Lin}=500 \mu \mathrm{H}$ \\
\hline Capacitor & $\mathrm{Cr}=470 \mu \mathrm{F} \mathrm{Co}=1000 \mu \mathrm{F}$ \\
\hline Switching Frequency & $10 \mathrm{kHz}$ \\
\hline
\end{tabular}

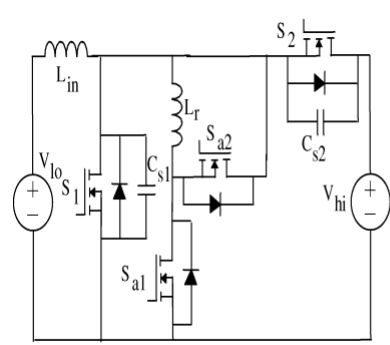

(a)

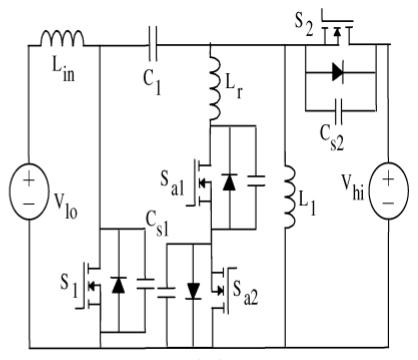

(b)
Figure 2. Earlier proposed bidirectional converters (a) converter proposed in ${ }^{9}$ (b) converter proposed in $^{10}$.

power flow with high efficiency and reduced losses ${ }^{13}$. An architecture of On Chip switched capacitor ${ }^{14}$ produced reduced ripple voltage with high switching frequency. In quasi Z-source impedance networks implemented to produce an output voltage and current with reduced ripple ${ }^{15}$. Advanced vehicles ${ }^{16}$, i.e. parameters and characteristics of vehicles estimated by DC-DC converter.

Because of the myths of the existing methods such as maximum current stress, variable switching frequencies, those methods are not preferred. In the proposed converter, operation will be discussed and Simulation results are obtained by using matlab Simulink. Now, in the next section we are going to discuss about Modeling of the proposed converter, operation of converter and simulation results.

\section{Proposed Bi-Directional Active Clamped Converter}

\subsection{Proposed Converter}

A new ZVS based soft switching technique is proposed for Bi-directional direct current to direct current converter. In this converter we will use a single auxiliary Active circuit. The proposed one (Figure 3 ) and the conventional one (Figure 1) is almost similar only difference is one 


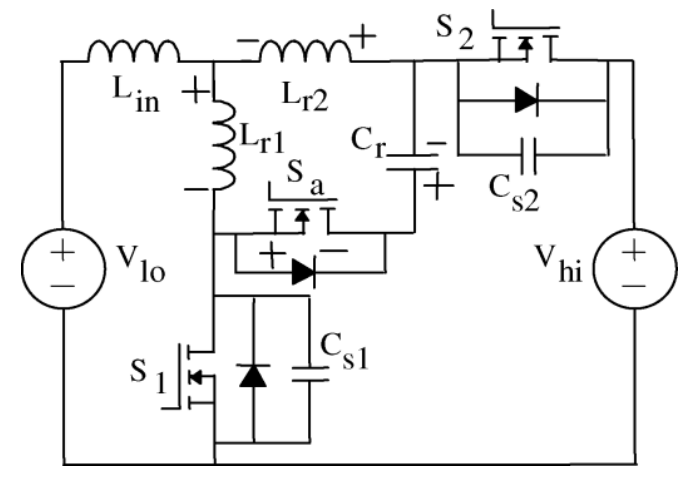

Figure 3. Proposed soft-switched Non-isolated DC-DC converter. auxiliary switch, one capacitor and two inductors. These elements make the circuit simple, which is well accepted Active clamp technique and these are used to operate in Boost/Buck mode with main switches $\mathrm{S}_{1}$ and $\mathrm{S}_{2}$. This converter is made to operate with continuous flow of inductor current, constant frequency is used to turn $\mathrm{ON}$ and turn OFF the switches.

Modes of operation of converter goes through two modes, one is Boosting mode, and another is Bucking mode. The Figure 4, Figure 5 represents equivalent circuit diagrams for both operations. The waveforms for both modes of operation are shown in Figure 6. From Figure 3

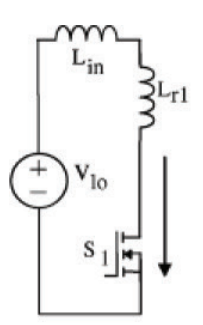

(a)

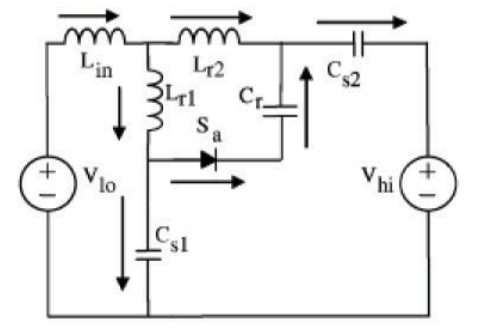

(b)

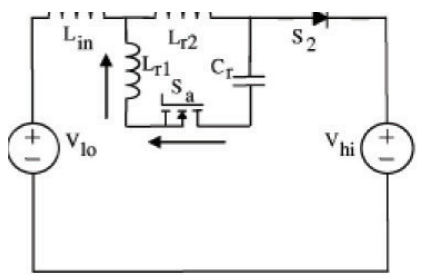

(e)

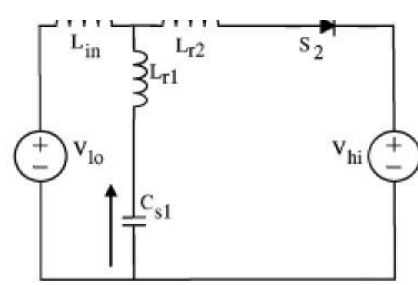

(f)

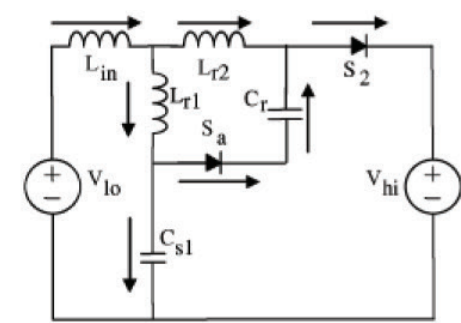

(c)

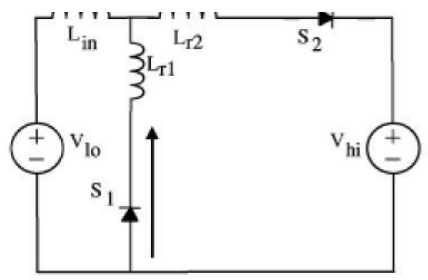

(g)

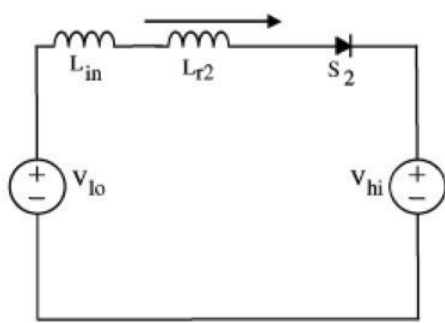

(d)

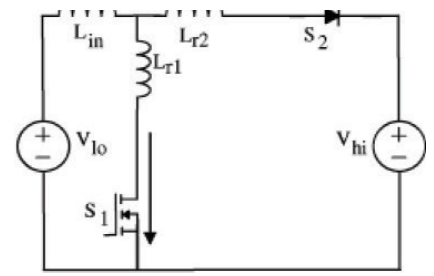

(h)

Figure 4. Equivalent circuit diagrams from Mode 0 to Mode 7 of boost operation.
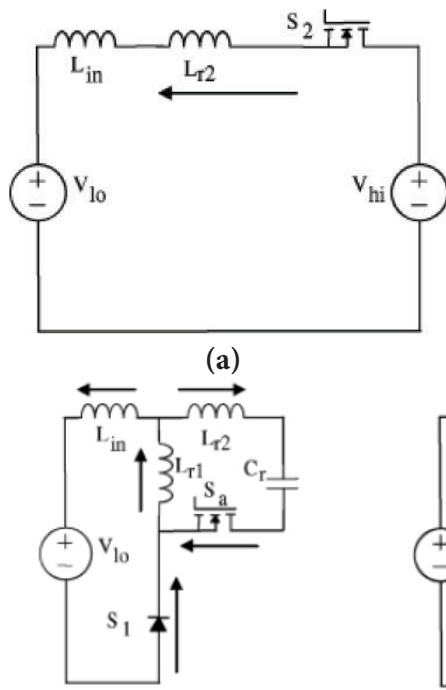

(e)

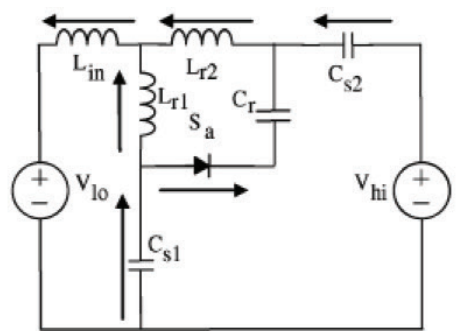

(b)

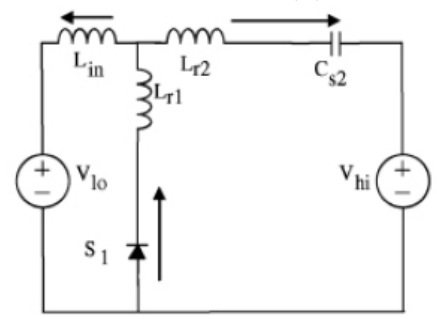

(f)

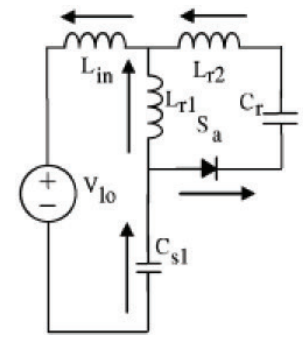

(c)

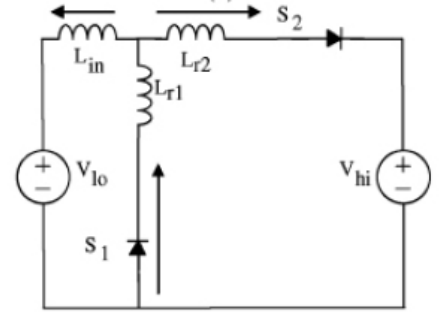

(g)

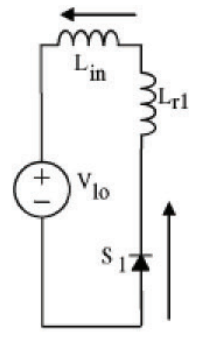

(d)

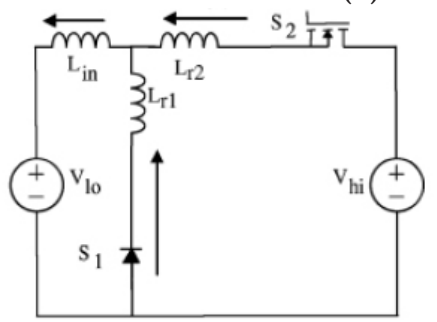

(h)

Figure 5. Equivalent circuit diagrams from Mode 0 to Mode 7 of buck operation. 


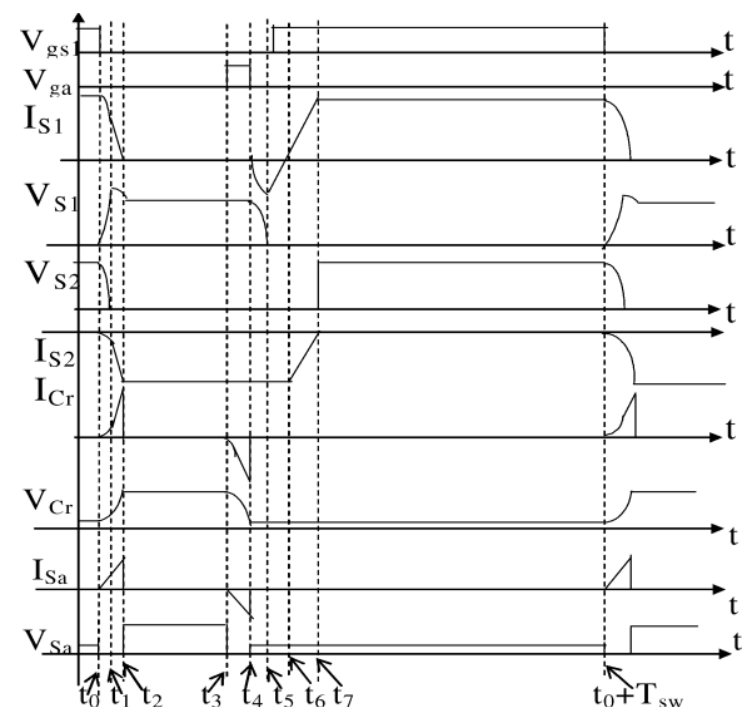

Figure 6. Converter waveforms for Boost and Buck operation.

it is seen that the current entering through inductor $\left(\mathrm{I}_{\mathrm{Lr} 1}\right)$ is positive if it enters through positive terminal. The capacitor current is positive at positive terminal of capacitor Cr.

\subsection{Modes of Operation of Bidirectional Converter in Boost Region}

Mode $0\left(t<t_{0}\right)$ : Earlier than $\mathrm{t}=\mathrm{t}_{0}$ when switch 1 is on, when current flowing through the inductor $\mathrm{L}_{\text {in, }}$ current in the inductor starts increasing, the converter is going to operate as a Boost converter

Mode $1\left(t_{0}<t<t_{1}\right)$ : During time $\mathrm{t}=\mathrm{t}_{0}$ switch 1 is going to turn off, voltage at Switch1 is slendered by capacitor $\left(\mathrm{C}_{\mathrm{s1}}\right)$ connected across it. Current starts flowing in $\mathrm{Cr}$ when current $\left(\mathrm{L}_{\mathrm{r} 1}\right)$ charges $\left(\mathrm{C}_{\mathrm{s1}}\right)$. Also in this mode current is delivered to $\left(\mathrm{L}_{\mathrm{r} 2}\right)$ and the capacitance at switch2, $\mathrm{C}_{\mathrm{s} 2}$, starts discharging

Mode $2\left(t_{1}<t<t_{2}\right)$ : This is continuation of mode 1 but the current at $\mathrm{t}=\mathrm{t}_{1}$ through $\left(\mathrm{C}_{\mathrm{s} 2}\right)$ is not completely discharged and the current flows through antiparallel diode across switch 2

Mode $3\left(t_{2}<t<t_{3}\right)$ : At $\mathrm{t}=\mathrm{t}_{2}$ the it acts as boost converter and current through the active clamping circuit stops flowing. As negative voltage is appeared across $L_{i n}$, the current through this inductor reduces.

Mode $4\left(t_{3}<t<t_{4}\right)$ : At $\mathrm{t}=\mathrm{t}_{3}$ before the switch1 is on, Auxiliary switch $\left(\mathrm{S}_{\mathrm{a}}\right)$ is on with Zero-Current Switching (ZCS). The current through $\mathrm{C}_{\mathrm{r}}$ starts discharging through $\left(\mathrm{L}_{\mathrm{r} 1}\right.$ and $\left.\mathrm{Lr}_{2}\right)$ since $\mathrm{I}_{\mathrm{Lin}}$ tends to reduce.
Table 2. Output results of the proposed converter

\begin{tabular}{|c|c|}
\hline Parameters & Magnitude \\
\hline Output voltage & $63.5 \mathrm{~V}$ \\
\hline Output power & $270 \mathrm{~W}$ \\
\hline
\end{tabular}

Mode $5\left(t_{4}<t<t_{5}\right)$ : During this, Current in inductor $\left(\mathrm{L}_{\mathrm{r} 1}\right)$ begins to flow through the output capacitor of switch 1 when the Auxiliary switch $(\mathrm{Sa})$ is made to be opened .Voltage drop across the switch 1 is Zero because the capacitor $\mathrm{C}_{s 1}$ discharges through switch 1 .

Mode $6\left(t_{5}<t<t_{6}\right)$ : During $\mathrm{t}=\mathrm{t}_{5}$ the capacitor $\left(\mathrm{C}_{\mathrm{sl}}\right)$ is drained and the anti-parallel diode will $\mathrm{ON}$ and turn on the switch at this particular time.

Mode $7\left(t_{6}<t<t_{7}\right)$ : switch 1 is $\mathrm{ON}$ at $\mathrm{t}=\mathrm{t}_{6}$, later the current $\left(I_{\text {Lrl }}\right)$ reverses its path of flow so current path takes place from inductor $\mathrm{L}_{\mathrm{r} 2}$ to switch 1 .

\subsection{Modes of Operation of Bidirectional Converter in Buck Region}

Mode $0\left(t<t_{0}\right)$ : Before $\mathrm{t}=\mathrm{t}_{0}$ when the switch $\mathrm{S}_{2}$ is on, the converter is going to operate as a Buck converter and the current through $\mathrm{L}_{\text {in }}, \mathrm{I}_{\mathrm{Lin}}$ starts raising.

Mode $1\left(t_{0}<t<t_{1}\right)$ : At time $\mathrm{t}=\mathrm{t}_{0} \mathrm{~S}_{2}$ is going to turn off and voltage across Switch $\mathrm{S}_{2}$ is limited by capacitor $\left(\mathrm{C}_{\mathrm{s} 2}\right)$ connected across it. The current starts flowing through $\mathrm{Cr}$ when current through $\mathrm{L}_{\mathrm{r} 1}$ charges up $\mathrm{C}_{\mathrm{s1}}$. Also in this mode input current is delivered to $\mathrm{L}_{\mathrm{r} 1}$ and the capacitance across $\mathrm{S}_{1}, \mathrm{C}_{\mathrm{s1}}$, starts discharging.

Mode $2\left(t_{1}<t<t_{2}\right)$ : This mode is continuation of mode 1 but the current through $\mathrm{C}_{\mathrm{s} 2}$ is completely discharged at $\mathrm{t}=\mathrm{t}_{1}$ and $\mathrm{C}_{\mathrm{s1}}$ may or may not be completely discharged and current stops flowing through $\mathrm{C}_{\mathrm{r}}$.

Mode $3\left(t_{2}<t<t_{3}\right)$ : At time $\mathrm{t}=\mathrm{t}_{2}$ the converter operates as boost converter and the current through the active clamping circuit stops flowing. As negative voltage is appeared across $\mathrm{L}_{\mathrm{in}}$, the current through this inductor reduces and converter operates in freewheeling mode.

Mode $4\left(t_{3}<t<t_{4}\right)$ : At time $\mathrm{t}=\mathrm{t}_{3}$ before the $\mathrm{S}_{1}$ is to be turned on, Auxiliary switch $\left(S_{\mathrm{a}}\right)$ is turned on with ZeroCurrent Switching (ZCS). The current through $\mathrm{C}_{\mathrm{r}}$ starts discharging through $\mathrm{L}_{\mathrm{r} 1}$ and $\mathrm{L}_{\mathrm{r} 2}$ since $\mathrm{I}_{\mathrm{Lin}}$ tends to reduce.

Mode $5\left(t_{4}<t<t_{5}\right)$ : Auxiliary switch $\left(\mathrm{S}_{\mathrm{a}}\right)$ is turned off at time $\mathrm{t}=\mathrm{t}_{4}$ the current passing through inductor $\left(\mathrm{L}_{\mathrm{r} 2}\right)$ is used to discharge capacitor $\left(\mathrm{C}_{\mathrm{s} 2}\right)$.

Mode $6\left(t_{5}<t<t_{6}\right)$ : At time $\mathrm{t}=\mathrm{t}_{5}$ the capacitor $\mathrm{C}_{\mathrm{s} 2}$ is completely discharged and the anti- parallel diode is going 
to conduct which is across switch $S_{2}$.we can turn on the switch at this instant.

Mode $7\left(t_{6}<t<t_{7}\right)$ : After switch 2 is turned on at $\mathrm{t}=\mathrm{t}_{6}$ the direction of the current is reversed and the current is transfer from its inductor $\mathrm{L}_{\mathrm{r} 1}$ to switch 2 .

Now, we are going to discuss about the Matlab simulation results in the next section.

\section{Results and Discussions}

The simulation of the proposed converter is done through Matlab Simulink environment. This circuitry was designed to work at lower side voltage of $\mathrm{V}_{10}=36 \mathrm{~V}$ and high voltage of $\mathrm{V}_{\mathrm{hi}}=70 \mathrm{~V}$ as shown in Figure 7., Highest rating of power is $270 \mathrm{~W}$, and the frequency is used turn $\mathrm{ON}$ and turn OFF the switches are of $10 \mathrm{kHz}$.In this Bidirectional DC-DC converter we use PV as High voltage and Battery as Low Voltage sources. The Bidirectional converter can perform both buck and boost mode of operations.

Figure 8 depicts you a Matlab circuit of Bidirectional circuitry. This consists two switches (MOSFETS), Inductors $\left(\mathrm{L}_{\mathrm{in}}, \mathrm{L}_{\mathrm{r} 1}, \mathrm{~L}_{\mathrm{r} 2}\right)$ and capacitor $\left(\mathrm{C}_{\mathrm{r}}\right)$. Pulse generation circuit is also shown in the Figure 8. The switching frequency is $10 \mathrm{kHz}$.

In Figure 9 Input voltage and current waveforms from PV panel are shown i.e $\mathrm{V}_{\text {in }}=64.5 \mathrm{~V}, \mathrm{I}_{\text {in }}=5.2 \mathrm{~A}$, In Figure 10 output voltage and current delivered to load are shown i.e, $\mathrm{V}_{\text {out }}=63.5 \mathrm{~V}, \mathrm{I}_{\text {out }}=4.2 \mathrm{~A}$. and you can observe that there is drop in voltage and current. The output is ripple free in both voltage and current. In Figure 11 Buck voltage is shown which is used to charge the battery and the voltage to battery is $35.3 \mathrm{~V}$ and the output is pure DC with less ripple content. This Buck Operation is done by Bidirectional

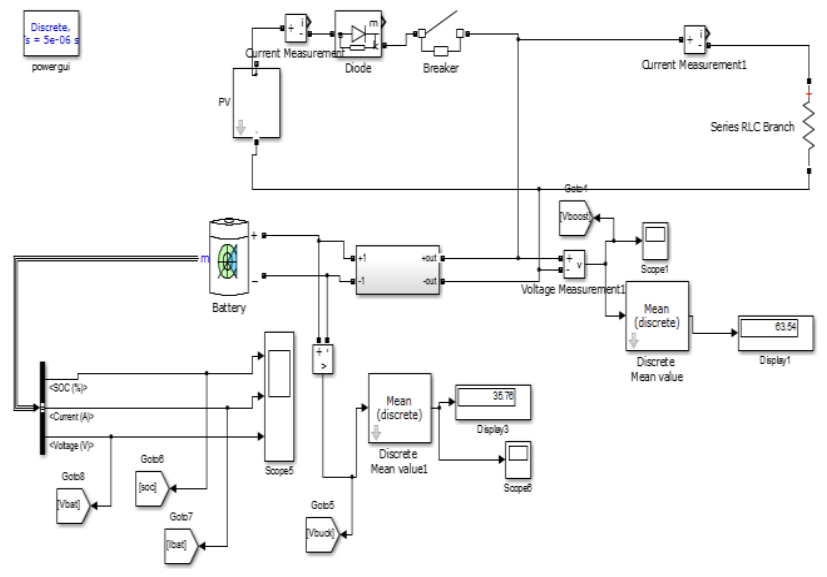

Figure 7. Simulation Circuit of proposed system.

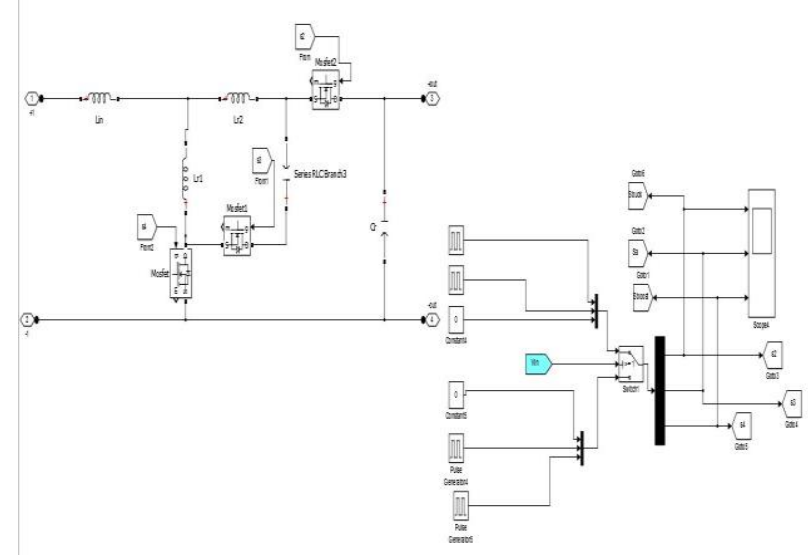

Figure 8. Simulation circuit of Bi-directional converter.
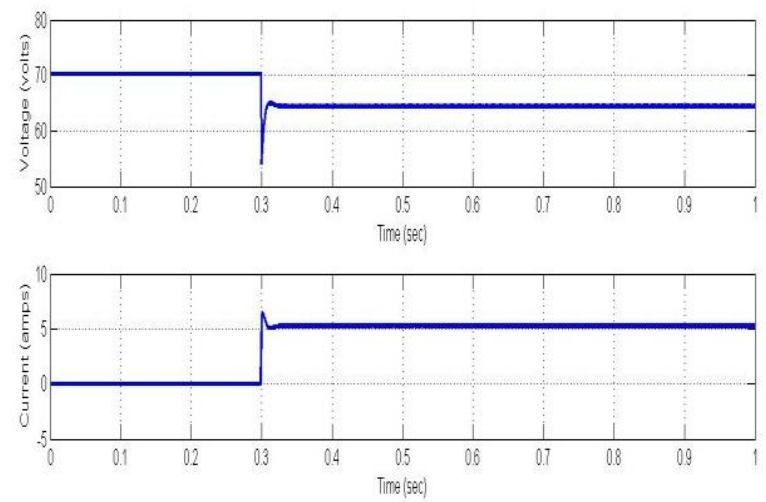

Figure 9. Input Voltage and current waveforms $\mathrm{V}_{\text {in }}=64.5$ $\mathrm{V}, \mathrm{I}_{\text {in }}=5.2 \mathrm{~A}$.
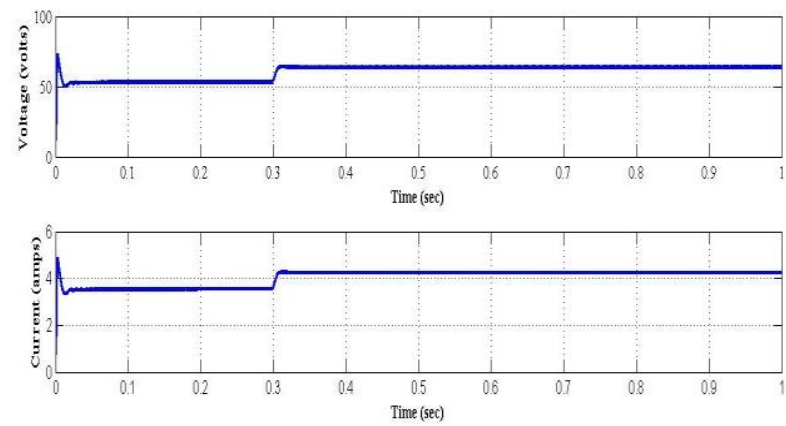

Figure 10. Output Voltage and current waveforms $\mathrm{V}_{\text {out }}=$ $63.5 \mathrm{~V}, \mathrm{I}_{\text {out }}=4.2 \mathrm{~A}$.

converter. In Figure 12 Boost voltage is shown which is given by battery source and it is delivered to load and the voltage is constant after certain time period. In Figure 13 the battery SOC (State of Charge) which is $50 \%$ means the battery is in charging condition which is linear in nature and voltage of $35.75 \mathrm{~V}$, current of $4.7 \mathrm{~A}$ is shown. 


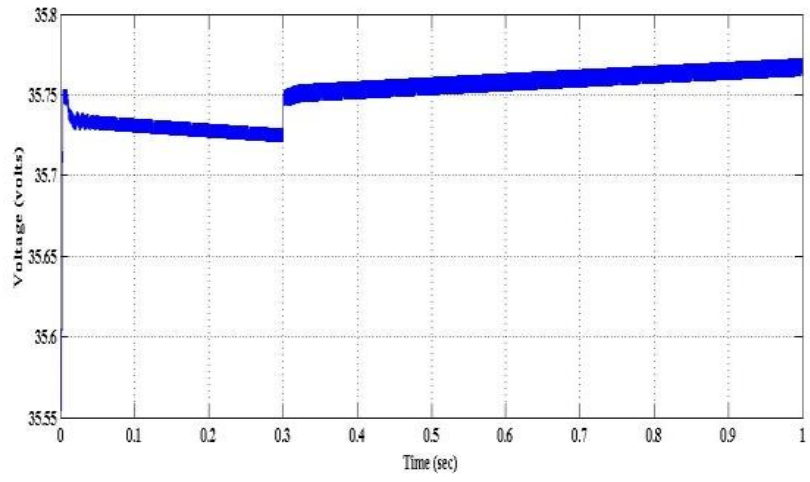

Figure 11. Buck Voltage supplied to battery $\mathrm{V}_{\text {Buck }}=35.3 \mathrm{~V}$.

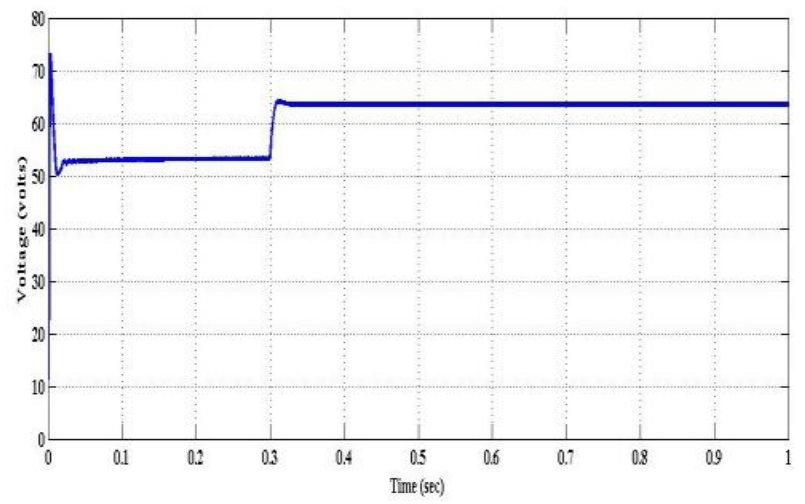

Figure 12. Boost Voltage supplied to load $\mathrm{V}_{\text {Boost }}=63.54 \mathrm{~V}$.
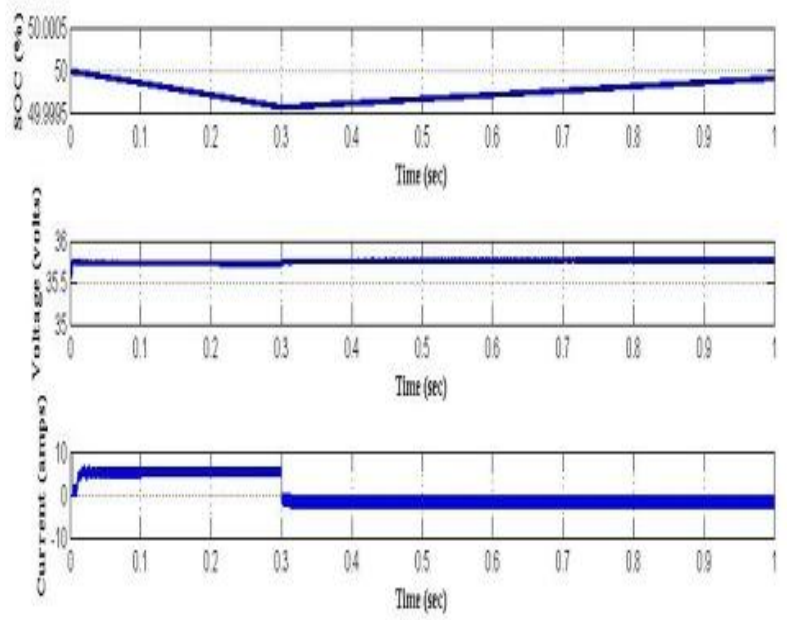

Figure 13. Simulation result of battery voltage $=35.75 \mathrm{~V}$, current $=4.7 \mathrm{~A}, \mathrm{SOC}=50 \%$.

\section{Conclusion}

A new DC-DC Bidirectional converter is implemented and the features of this circuitry are flow of current through inductor is continuous, constant frequency of switching, switch stress are less due to the usage of Auxiliary circuit. The simulation results are shown by using Matlab Simulink. The typical voltage, current waveforms are unveiled.

\section{References}

1. Jain M, Daniele M, and Jain PK. A bidirectional DC-DC converter topology for low power application. IEEE Trans Power Electron. Jul 2000; 15(4):595-606. doi: $10.1109 / 63.849029$

2. Zhiguo K, Chunbo Z, Shiyan Y, Shukang C. Study of bidirectional DC-DC converter for power management in electric bus with supercapacitors. In Proceedings of IEEE VPPC Conference Rec. 2006. p. 1-6. doi: 10.1109/ VPPC.2006.364376

3. Henze CP, Martin HC, Parsley DW. Zero voltage switching in high frequency power converters using pulse width modulation. In Proceedings of IEEE APEC Conference Rec. 1988. p. 33-40. doi: 10.1109/APEC.1988.10548

4. Sable DM, Lee FC. A zero-voltage-switching bidirectional battery charger/discharger for NASA EOS satellite. In Proceedings of IEEE APEC Conference Rec. 1992. p. 614-21. doi:10.1109/APEC.1992.228354

5. Martinez ZR, Ray B. Bidirectional DC/DC power conversion using constant frequency multi-resonant topology. In Proceedings of IEEE APEC Conference. Rec. 1994. p. 991-7. doi:10.1109/APEC.1994.316291

6. Kim C-E, Han S-K, Yi K-H, Lee W-J, Moon G-W. A new high efficiency ZVZCS bi- directional DC/DC converter for $42 \mathrm{~V}$ Power System of HEVs. In Proceedings of IEEE PESC Conference Rec. 2006. p. 792-7. doi:10.1109/ PESC.2005.1581717

7. Chau KT, Ching TW, Chan CC. Bidirectional softswitching converter-fed DC motor drives. In Proceedings of IEEE PESC Conference Rec. 1998. doi:10.1109/ PESC.1998.701932

8. Shiji H, Harada K, Ishihara Y, Todaka T, Alzamora G. A zero voltage-switching bidirectional converter for PV systems. In Proceedings of IEEE INTELEC Conference Rec. 2003. p. 14-9. doi: 10.1109/INTLEC.2003.1252085

9. Sanchis-Kilders E, Ferreres A, Maset E, Ejea JB, Esteve V, Jordan J, Garrigos A, Calvente J. Soft switching bidirectional converter for battery discharging-charging. In Proceedings of IEEE APEC Conference Rec. 2006. p. 603-9. doi: 10.1109/APEC.2006.1620600

10. Kim I-D, Paeng S-H, Ahn J-W, Nho E-C, Ko J-S. New bidirectional ZVS PWM c Sepic/Zeta DC-DC converter. In Proceedings of IEEE ISIE Conference Rec. 2007. p. 555-60. doi: org/10.6113/JPE.2014.14.4.649

11. Schuch L, Rech C, Hey HL, Grundlinggrundling HA, Pinheiro H, Pinheiro JR. Analysis and design of a new 
high-efficiency bidirectional integrated ZVT PWM converter for DC-bus and battery-bank interface. IEEE Trans Ind Appl. Sep 2006; 42(5):1321-32. doi: 10.1109/ TIA.2006.880847

12. Saravanan T, Srinivasan V, Sandiya VP. A two stage DC-DC converter with isolation for renewable energy applications. Indian Journal of Science and Technology. Jun 2013; 6(S6). Doi no: 10.17485/ijst/2013/v6i6/33970

13. Kavya Santhoshi B, Mohana Sundaram K, Sivasubramanian M, Akila S. A novel multiport bidirectional dual active bridge DC-DC converter for renewable power generation systems. Indian Journal of Science and Technology. Jan 2016; 9(1). Doi no: 10.17485/ijst/2016/v9i1/85701
14. Jagannadha Naidu K, Harish MK. On chip DC-DC converter with high switching frequency and low ripple voltage. Indian Journal of Science and Technology. Feb 2016; 9(5). Doi no: 10.17485/ijst/2016/v9i5/87171

15. Shobanadevi N, Krishnamurty V, Stalin N. PISB control of single phase quasi impedance source DC-DC converter. Indian Journal of Science and Technology. July 2015; 8(13). Doi no:10.17485/ijst/2015/v8i13/55446

16. Kirill S, Timofey G, Vladimir Y. Method for calculating the power circuit characteristics of the Isolated DC-DC converters for electric and hybrid vehicles. Indian Journal of Science and Technology. Oct 2015; 8(27). Doi no: 10.17485/ ijst/2015/v8i27/81709 